\title{
ASSOCIATION OF KNOWLEDGE AND FAMILY SUPPORT WITH PREMARITAL SEX AMONG STREET CHILDREN IN MEDAN, NORTH SUMATERA
}

\author{
Vini Vidi Vici Sitinjak
}

Masters Program in Public Health, Faculty of Public Health

\begin{abstract}
Background: The concept 'street children' and/or 'street kid' encompasses any child or adolescent under the age of eighteen who works and/or lives in the street alone or with his or her family or asylum seekers who are technically homeless and without support. This study aimed to assess the association of knowledge and family support with premarital sex among street children in Medan, North Sumatera.

Subjects and Method: This was a cross-sectional study conducted at KKSP Foundation in Medan, North Sumatera. A sample of street children was selected for this study by purposive sampling. The dependent variable was premarital sex. The independent variables were knowledge and family support. The data were collected by questionnaire and analyzed by a multiple logistic regression.

Results: Poor knowledge $(\mathrm{OR}=2.34 ; \mathrm{p}=0.019)$ and weak family support $(\mathrm{OR}=$ $3.10 ; \mathrm{p}=0.003$ ) were associated with an increased risk of premarital sex.

Conclusion: Poor knowledge and weak family support are associated with an increased risk of premarital sex among street children.
\end{abstract}

Keywords: knowledge, family support, premarital sex, street children

\section{Correspondence:}

Vini Vidi Vici Sitinjak. Masters Program in Public Health, Faculty of Public Health, Universitas Sumatera Utara, Medan, North Sumatera.

Email: vinisitinjak@gmail.com. Mobile: 082165006421

The 4th International Conference on Public Health

Best Western Premier Hotel, Solo, Indonesia, August 29-30, 2018 | 129 https://doi.org/10.26911/theicph.2018.02.10 